\title{
BEAM-TO-COLUMN CONNECTION CALCULATIONS USING ROBOT SOFTWARE
}

\author{
Mykhaylo Pashechko', Anna Latos ${ }^{2}$ \\ 1 Department of Fundamentals of Technology, Lublin University of Technology, Nadbystrzycka 38 St., 20-618 \\ Lublin, Poland, e-mail: m.paszeczko@pollub.pl \\ 2 Doctoral student at the Lublin University of Technology, e-mail: anna.latos@op.pl
}

Received: 2015.06.05 Accepted: 2015.08.05 Published: 2015.09.01

\begin{abstract}
A beam-to-column connection design and results of engineer calculations using Autodesk's Robot Structural analysis are shown in the article. Two types of connections, bolted and welded, were calculated. The tensile resistance amounted to $912.74 \mathrm{kN}$, bending resistance to $100.87 \mathrm{kN} \cdot \mathrm{m}$ and effective design capacity of the bolt amounted to $27.69 \mathrm{kN}$. Normal stress in the weld amounted to $\sigma_{\perp \max }=\tau_{\perp \max }=72.72 \mathrm{MPa}$, in the vertical weld to $\sigma_{\perp}=\tau_{\perp}=63.34 \mathrm{MPa}$ and tangent stress amounted to $\tau_{\|}=4.37 \mathrm{MPa}$. The results allowed us to implement minor changes such as increasing the distance between the bolt and the edge and decreasing the size of the fillet welds. The design is fully compliant with the EN 1993-1-8 norm. Using Robot Structural Analysis substantially increased the pace of calculations giving precise and clear outcomes.
\end{abstract}

Keywords: structural connections, engineering calculations, robot software.

\section{INTRODUCTION}

Computer assistance in an engineer's work is currently getting more effective and precise. The automation of the design process makes the time of project completion shorter and increases competitiveness of a product [3]. Autodesk's Robot Structural Analysis is one of the tools facilitating the work of designers and constructors $[1,3]$.

Autodesk Robot Structural Analysis is an integrated graphic application used for modeling, analysis and dimensioning of various construction types. The program features construction design, carrying out static calculations of a construction, outcomes verification, standardized calculations of construction elements and gathering documentation for calculated and dimensioned constructions. The most relevant features of the Robot include:

- a fully graphic definition of construction in the graphic editor (loading a DXF file containing construction geometry prepared with a different program is also possible).
- a possibility of a graphic representation of the designed construction as well as displaying various calculation outcomes (force, displacement, multiple windows work etc.)

- calculation of the construction (dimensioning) while designing another construction (multithreading),

- carrying out static and dynamic construction analyses,

- assigning the rod type while creating the construction model, not in standard modules.

- composing any type of print (calculation notes, screenshots, print composition, exporting objects to other programs) [1].

\section{DESIGN OF CONSTRUCTIONAL CONNECTION}

The main function of the connection is to distribute the internal forces between the elements. In a steel construction basic elements such as columns, beams, bracings and ties are used. Next, the components of the external building parti- 
tions-ceilings and partition walls - are attached to the main constructional elements. The most commonly used connection types in multi-storey buildings are $[2,4,5]$ :

- articulated nominal connections (beam-tobeam and beam-to-column),

- moment connections (beam-to-column) in case of continuous frames,

- bracings connections,

- column bases.

A type of beam-to-column constructional connection was designed using Robot Structural Analysis software (Fig. 1). The column is an Hsection of an IPE 220 profile and the beam of an IPE 200 profile. St3S steel was used in both parts.

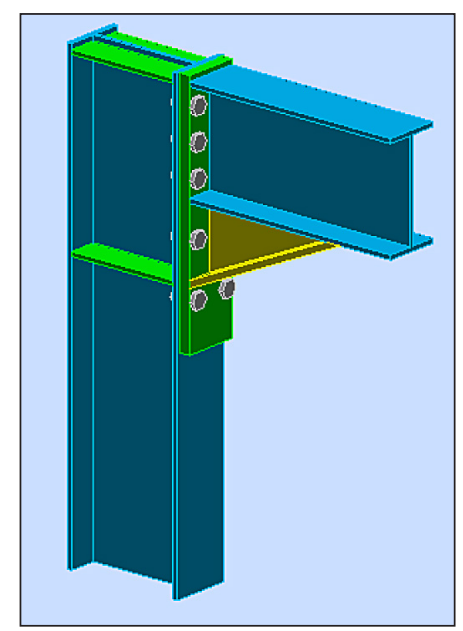

Fig. 1. Beam-to-column connection model
The type of connection, material and profiles geometry were chosen before the calculations. The parameters, e.g. forces and moments, can be set automatically with possible manual modifications in the edition mode.

For this particular connection bolted and welded connections were planned. There were five rows and three columns of 10.9 grade bolds. Filled welds of the following size were used: column web weld $\mathrm{a}_{\mathrm{w}}=4 \mathrm{~mm}$, flange weld $\mathrm{a}_{\mathrm{f}}=7 \mathrm{~mm}$, stiffener weld $\mathrm{a}_{\mathrm{s}}=4 \mathrm{~mm}$ and horizontal weld $\mathrm{a}_{\mathrm{fd}}$ $=5 \mathrm{~mm}$. The loads put on a beam-to-column connection:

- bending moment $\mathrm{M}_{\mathrm{d}}=50 \mathrm{kN} \cdot \mathrm{m}$,

- shear force $\mathrm{V}_{\mathrm{d}}=10 \mathrm{kN}$,

- axial force $\mathrm{N}_{\mathrm{d}}=10 \mathrm{kN}$,

- bending moment in the lower column $\mathrm{M}_{\mathrm{cld}}=$ $50 \mathrm{kN} \cdot \mathrm{m}$,

- shear force in the lower column $\mathrm{V}_{\mathrm{cld}}=10 \mathrm{kN}$,

- axial force in the lower column $\mathrm{N}_{\mathrm{cld}}^{\mathrm{cld}}=10 \mathrm{kN}$.

The sizes and loads in this particular project are presented in Figure 2.

\section{ENGINEER CALCULATIONS OUTCOMES}

The next step using Robot Structural Analysis was to carry out engineer calculations and control calculations to verify the bolt arrangements. Table 1 shows the outcomes of the calculations. Next, calculation and verification of the used fillet welds were performed. Table 2 shows the outcomes.

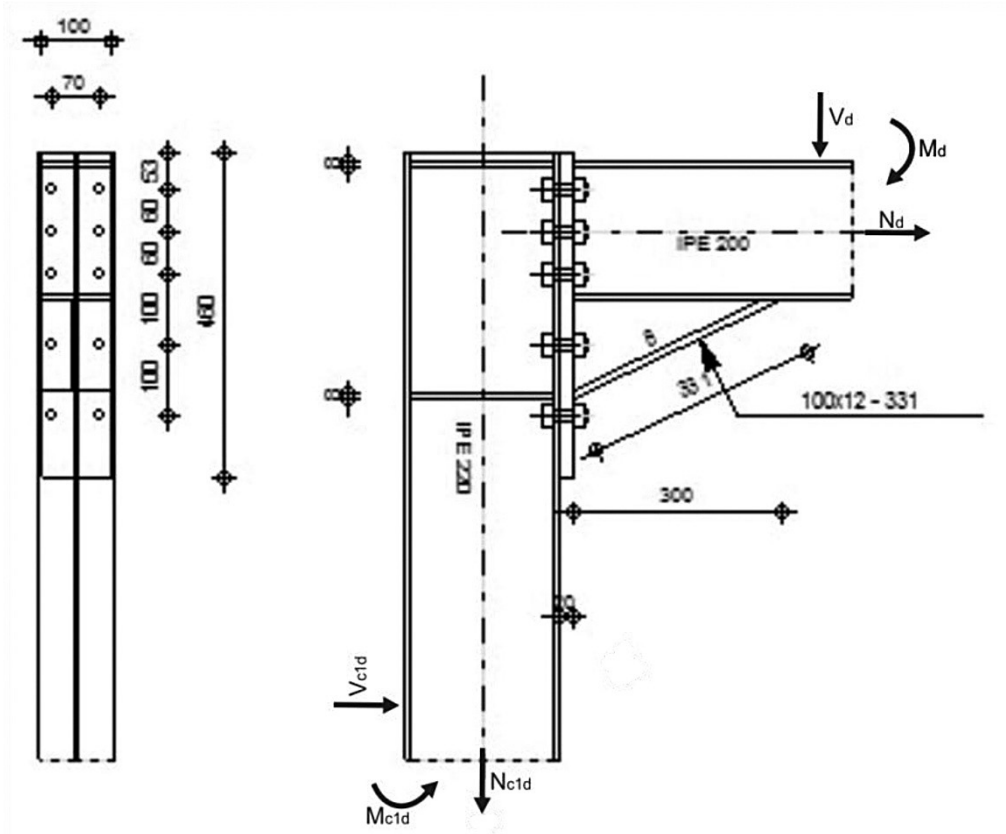

Fig. 2. Sizes and loads 
Table 1. Calculations outcomes and bolt arrangement control

\begin{tabular}{|c|c|c|c|c|}
\hline \multicolumn{5}{|c|}{ Single bolt resistance } \\
\hline$S_{R t}=$ & 10.13 & {$[\mathrm{kN}]$} & Bolt resistance for shank fracture & $S_{R t}=\min \left(0.65 R_{m} A_{s}, 0.85 R_{e} A_{s}\right)$ \\
\hline$S_{R r}=$ & 90.21 & {$[\mathrm{kN}]$} & Bolt resistance for loss of contact area & $\mathrm{S}_{\mathrm{Rr}}=0.85 \mathrm{~S}_{\mathrm{Rt}}$ \\
\hline$S_{R v}=$ & 58.78 & {$[\mathrm{kN}]$} & Bolt resistance for shank shear rupture & $\mathrm{S}_{\mathrm{Rv}}=0.45 \mathrm{~m} \mathrm{R} \mathrm{m}_{\mathrm{m}} 0.8 \mathrm{~A}_{\mathrm{s}}$ \\
\hline$S_{\mathrm{Rb}}=$ & 27.69 & {$[\mathrm{kN}]$} & Bearing resistance & $\begin{array}{l}\mathrm{S}_{\mathrm{Rb}}=\min \left(a \mathrm{f}_{\mathrm{dc}} 0.7 \mathrm{~d} \sum \mathrm{t}_{\mathrm{i}}, \mathrm{a} \mathrm{f}_{\mathrm{dp}} 0.7\right. \\
\left.\mathrm{d} \sum \mathrm{t}_{\mathrm{i}}\right)\end{array}$ \\
\hline \multicolumn{5}{|c|}{ Check of front plate thickness } \\
\hline$c=$ & 16 & [mm] & $\begin{array}{l}\text { Distance between weld and edge of bolt } \\
\text { opening }\end{array}$ & \\
\hline $\mathrm{b}_{\mathrm{s}}=$ & 50 & {$[\mathrm{~mm}]$} & Width of plate cooperation per one bolt & $b_{s}=\min \left(2.0^{*}(c+d), b_{c} / 2\right)$ \\
\hline$t_{\min 1}=$ & 15 & [mm] & $\begin{array}{l}\text { Minimal plate thickness for simple connections } \\
\text { in tension }\end{array}$ & $\mathrm{t}_{\min 1}=1.2 \sqrt{ }\left(\mathrm{c} \mathrm{S}_{\mathrm{Rt}} /\left(\mathrm{b}_{\mathrm{s}} \mathrm{f}_{\mathrm{d}}\right)\right)$ \\
\hline$t_{\min 2}=$ & 16 & {$[\mathrm{~mm}]$} & $\begin{array}{l}\text { Minimal plate thickness for other connections } \\
\text { in tension and bending }\end{array}$ & $t_{\min 2}=d\left(R_{m} / 1000\right)^{1 / 3}$ \\
\hline$t_{p} B t_{\text {min2 }}(83)$ & $|20|>16$ & verified & $-0,81$ & \\
\hline \multicolumn{5}{|c|}{ Parameters of bolt arrangement } \\
\hline$b=$ & 1.34 & & Leverage effect coefficient & $\mathrm{b}=2.67-\mathrm{t} / \mathrm{t}_{\min }$ \\
\hline$h_{0}=$ & 329 & [mm] & Distance between axes of beam flanges & \\
\hline $\mathrm{y}_{\min }=$ & 197 & {$[\mathrm{~mm}]$} & Minimal arm of forces in bolts & $y_{\min }=0.6 h_{0}$ \\
\hline \multicolumn{5}{|c|}{ Bolt distances from the rotation axis and load distribution factors } \\
\hline Bolt no. & $m_{i}$ & $y_{i}$ & $y_{\text {ired }}$ & $\mathrm{W}_{\mathrm{tNi}}$ \\
\hline 1 & 2 & 291 & - & 1 \\
\hline 2 & 2 & 231 & - & 0,8 \\
\hline 3 & 2 & 171 & - & 0,8 \\
\hline 4 & 2 & 71 & - & 1 \\
\hline 5 & 2 & -29 & - & 0.7 \\
\hline \multicolumn{5}{|c|}{ Bolt arrangement check due to rupture } \\
\hline$N_{\text {Rjt }}=$ & 912.74 & {$[\mathrm{kN}]$} & Tensile resistance & $\mathrm{N}_{\mathrm{Rjt}}=\mathrm{S}_{\mathrm{Rt}} \sum \mathrm{W}_{\mathrm{tNi}}(87)$ \\
\hline$M_{\mathrm{Rjt}}=$ & 100.87 & {$\left[\mathrm{kN}^{*} \mathrm{~m}\right]$} & Bending resistance & $M_{R j t}=S_{R t} \sum\left(m_{i} w_{t M i} y_{i}\right)(89)$ \\
\hline $\begin{array}{l}\mathrm{N}_{\mathrm{d}(+)} / \mathrm{N}_{\mathrm{Rit}}+\mathrm{M}_{\mathrm{d}} / \\
\mathrm{M}_{\mathrm{Rit}} \leq 1.0(85.88)\end{array}$ & $0.51<1,00$ & verified & $-0,51$ & \\
\hline \multicolumn{5}{|c|}{ Shear resistance per shear plane } \\
\hline$S_{v}=$ & 1 & {$[\mathrm{kN}]$} & Shear force in bolt with the highest ratio & \\
\hline$S_{R}=$ & 27.69 & {$[\mathrm{kN}]$} & Effective design capacity of a bolt & $S_{R}=\min \left(S_{R v}, S_{R b}\right)$ \\
\hline$S_{v} / S_{R} \leq 1.0$ & $0.04<1,00$ & verified & -0.04 & \\
\hline \multicolumn{5}{|c|}{ Check of tensile and shear resistance values of a single bolt } \\
\hline$S_{t}=$ & 53.77 & {$[\mathrm{kN}]$} & Tensile force in bolt with the highest ratio & \\
\hline$S_{v}=$ & 1 & {$[\mathrm{kN}]$} & Shear force in bolt with the highest ratio & \\
\hline $\begin{array}{l}\left(\mathrm{S}_{\mathrm{t}} / \mathrm{S}_{\mathrm{Rt}}\right)^{2}+\left(\mathrm{S}_{\mathrm{V}} /\right. \\
\left.\mathrm{S}_{\mathrm{Rv}}\right)^{2} \leq 1.0(74)\end{array}$ & $0.26<1.00$ & verified & -0.26 & \\
\hline
\end{tabular}

The last stage was to evaluate the forces and tension for frame corner and to verify the stability of the column web. Calculation outcomes are shown in Table 3. Tensile load resistance amounted to $912.74 \mathrm{kN}$ and bending resistance to 100.87 $\mathrm{kN} \cdot \mathrm{m}$. effective design capacity of the bolt calculated by the program amounted to $27.69 \mathrm{kN}$.

Normal stress in a weld amounted to $\sigma_{\perp \max }=$ $\tau_{\perp \max }=72.72 \mathrm{MPa}$, in the vertical weld to $\sigma_{\perp}=\tau_{\perp}=$
63.34 MPa and tangent stress to $\tau_{\|}=4.37 \mathrm{MPa}$. Stress due to bending and axial force in the frame corner amounted to 201.55 MPa and Column web resistance to $116.12 \mathrm{kN}$.

All the outcomes are compliant with the EN 1993-1-8 norm. Minor constructional changes, such as increasing the distance between the bolt and the edge and decreasing the size of the fillet welds, were implemented. 
Table 2. Calculation outcomes and fillet weld control

\begin{tabular}{|c|c|c|c|}
\hline \multicolumn{4}{|r|}{ Weld calculation } \\
\hline$A_{s}=$ & 59.6 & {$\left[\mathrm{~cm}^{2}\right]$} & Area of all welds \\
\hline$A_{s x}=$ & 36.74 & {$\left[\mathrm{~cm}^{2}\right]$} & Area of horizontal welds \\
\hline$A_{\mathrm{sy}}=$ & 22.86 & {$\left[\mathrm{~cm}^{2}\right]$} & Area of vertical welds \\
\hline$I_{\mathrm{sx}}=$ & 8903.77 & {$\left[\mathrm{~cm}^{4}\right]$} & Moment of inertia of the weld arrangement with respect to the hor. axis \\
\hline$y_{s}=$ & -80 & {$[\mathrm{~mm}]$} & Offset of weld centroid with respect to beam centroid \\
\hline$v_{y g}=$ & 183 & {$[\mathrm{~mm}]$} & Distance between upper weld edge and centroid of welds \\
\hline $\mathrm{v}_{\mathrm{yd}}=$ & 164 & {$[\mathrm{~mm}]$} & Distance between lower weld edge and centroid of welds \\
\hline$c=$ & 0.7 & & Resistance-dependent coefficient \\
\hline $\mathrm{s}_{\Lambda_{\max }}=\mathrm{t}_{\Lambda_{\max }}=$ & 72.72 & [MPa] & Normal stress in a weld \\
\hline $\mathrm{s}_{\wedge}=\mathrm{t}_{\wedge}=$ & 63.34 & {$[\mathrm{MPa}]$} & Stress in a vertical weld \\
\hline$t_{11}=$ & 4.37 & [MPa] & Tangent stress \\
\hline \multicolumn{4}{|r|}{ Weld check } \\
\hline 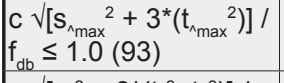 & $0.47<1,00$ & verified & -0.47 \\
\hline $\begin{array}{l}c \sqrt{ }\left[\mathbf{s}_{\Lambda}{ }^{2}+3^{*}\left(t_{\Lambda}{ }^{2}+t_{\|}{ }^{2}\right)\right] / / \\
f_{d b} \leq 1.0(93)\end{array}$ & $0.41<1,00$ & verified & -0.41 \\
\hline$\left|\mathrm{s}_{\lambda}\right| / \mathrm{f}_{\mathrm{db}} \leq 1.0(93)$ & $0.34<1,00$ & verified & -0.34 \\
\hline
\end{tabular}

Table 3. Engineer and control calculation outcomes for frame corner and column web

\begin{tabular}{|c|c|c|c|c|}
\hline \multicolumn{5}{|c|}{ Total equivalent stress } \\
\hline$s=$ & 201.55 & [MPa] & Stress due to bending and axial force & \\
\hline$t=$ & 0 & [MPa] & Shear stress & \\
\hline$\sqrt{ }\left[\mathrm{s}^{2}+3^{*} \mathrm{t}^{2}\right] / \mathrm{fds}_{\mathrm{ds}} \leq 1.0$ & $0.94<1,00$ & verified & -0.94 & \\
\hline \multicolumn{5}{|c|}{ Verification - level of beam upper flange: Web subjected to a concentrated force } \\
\hline$P_{t g}=$ & 156.07 & {$[\mathrm{kN}]$} & Tension force in web on the upper flange level & \\
\hline$P_{\mathrm{R}, \mathrm{fg}}=$ & 361.08 & {$[\mathrm{kN}]$} & Column web resistance & $\begin{array}{l}P_{R, f g}=\left(t_{f b}\left(t_{w c}+2 r_{c}\right)+7 t_{f c} t_{f c}\right) f_{d c} \\
+t_{h u}\left(b_{s}-t_{w c}\right) f_{d c}\end{array}$ \\
\hline$P_{t g} / P_{R, f g} \leq 1.0$ & $0.43<1,00$ & verified & -0.43 & \\
\hline \multicolumn{5}{|c|}{ Verification - level of beam lower flange: Web subjected to shear } \\
\hline$P_{v g}=$ & 156.07 & {$[\mathrm{kN}]$} & Shear force in web on the upper flange level & \\
\hline$P_{R, v g}=$ & 161.12 & {$[\mathrm{kN}]$} & Column web resistance & $P_{R, v g}=t_{w c} h_{c} f_{d c} / \sqrt{ } 3(16)$ \\
\hline$P_{v g} / P_{R, v g} \leq 1.0$ & $0.97<1.00$ & verified & -0.97 & \\
\hline \multicolumn{5}{|c|}{ Verification - level of beam lower flange: Web subjected to a concentrated force } \\
\hline$P_{c d}=$ & -146.07 & {$[\mathrm{kN}]$} & $\begin{array}{l}\text { Compression force in web on the lower flange } \\
\text { level }\end{array}$ & \\
\hline $\mathrm{h}_{\mathrm{d}}=$ & 0.79 & & Reduction factor for compression & $h_{d}=1.25-0.5 \mathrm{~s}_{c} / f_{d}(23)$ \\
\hline$c_{0 d}=$ & 154.5 & & Compression zone width & {$[4.2 .4]$} \\
\hline $\mathrm{k}_{\mathrm{cd}}=$ & 0 & & Reduction factor for calculations of $P_{R c}$ & {$[4.2 .4]$} \\
\hline$P_{R, w d}=$ & 333,53 & {$[\mathrm{kN}]$} & Column web resistance & $P_{R, w d}=c_{0 d} t_{w c} h_{d} f_{d c}+t_{h d}\left(b_{s}-t_{w c}\right) f_{d c}$ \\
\hline$P_{c d} / P_{R, w d} \leq 1.0$ & $0,44<1,00$ & verified & -0.44 & \\
\hline \multicolumn{5}{|c|}{ Verification - level of beam lower flange: Web subjected to shear } \\
\hline$P_{v d}=$ & 146.07 & {$[\mathrm{kN}]$} & Shear force in web on the lower flange level & \\
\hline$P_{R, v d}=$ & 161.12 & {$[\mathrm{kN}]$} & Column web resistance & $P_{R, v d}=t_{w c} h_{c} f_{d c} / \sqrt{ } 3(16)$ \\
\hline$P_{v d} / P_{R, v d} \leq 1.0$ & $0.91<1.00$ & verified & -0.91 & \\
\hline
\end{tabular}




\section{CONCLUSIONS}

Using Robot Structural Analysis for engineer calculations of beam-to-column connection type allowed us to evaluate bolted connection resistance, calculation of weld stress and verification of column web stability. All the outcomes were verified. They are fully compliant with the design and are resistant enough to the forces and moments. Using computer software, through automation, substantially increased the pace of work both while drawing the project and analyzing the data. Also, information about compliance with the norm and fulfilling the assumed endurance conditions was obtained.

\section{REFERENCES}

1. Autodesk. Podręcznik użytkownika. 2009, p. 3.

2. Poradnik architekta: Konstrukcje stalowe w Europie cz.1. Opracowanie Arcelor Mittal, Peiner Träger, Corus, Wydawnictwo Elamed, 27-28.

3. Kubicki K. Free vibrations of frames and their modeling in Autodesk Robot Structural Analysis program. Wydawnictwo Politechniki Częstochowskiej, Częstochowa 2012, p. 88.

4. Singer L.: Modern steel construction. „What's cool in steel", Sierpień 2009, p. 50.

5. Progress in Structural Engineering and Materials: The use of stainless steel in structures. Leroy Gardner, Kwiecień/Czerwiec 2005, 45-55. 